Huellas y recorridos

de una utopía.

La emigración italiana

en la Argentina

Fernanda Elisa

Bravo Herrera

Buenos Aires: Teseo, 2015.

\section{Formas de la meta viajera: emigración y exilio. (Re) visiones}

\author{
Graciela Beatriz Caram Catalano ${ }^{\bullet}$ \\ Universidad Nacional de Cuyo
}

Fernanda Elisa Bravo Herrera es salteña y descendiente de italianos de la Toscana, quienes - como tantos otros connacionales- abandonaron sus familias y terruño en busca de una vida mejor. Es investigadora del CONICET; Doctora en Literatura Comparada y Traducción de Textos Literarios; Magíster en Conservación y Gestión de Bienes Culturales y en Literatura Comparada por la Universidad de Siena; Licenciada en Letras por la Universidad Nacional de Salta. Publicó El Fondo de Mercedes de Tierras y Solares (1583-1589) del Archivo y Biblioteca Históricos de Salta (2010), Sátira politica y representaciones de género en la prensa de Salta a fines del siglo XIX (2010).

La obra referida fue realizada con financiamiento del CONICET y con auspicios de la Università di Siena y de la Universidad de Salta y ha contado también con un aporte suplementario del gobierno italiano a través de dos becas otorgadas a su autora.

El estudio, iniciado en 1999, se encuadra en un Proyecto de Investigación de mayor alcance: «La incidencia de la cultura italiana en la configuración del imaginario argentino del siglo XX", inscripto en el CONICET, donde Bravo Herrera lleva adelante sus investigaciones, cuya directora es la Dra. María Rosa Lojo y la co-directora la Prof. Zulma Palermo.

En el prólogo, el profesor Romano Luperini (Università degli Studi di Siena) manifiesta una doble importancia del aporte de la autora, gracias al cual logra llenar un vacío teórico-metodológico al tiempo que ahonda en textos ricos de voces variadas respecto de las diferentes modalidades discursivas entorno al complejo tema de la emigración. A continuación, el profesor Antonio Melis de la Universidad de Siena, destaca el rescate de la epopeya humilde, proeza, aventura e historia cotidiana a la vez de la inmigración italiana en la Argentina.

El estudio ofrece una mirada de las estructuraciones y configuraciones ideológicas del imaginario social italiano en torno a la emigración en la Argentina desde el siglo XIX hasta principios del XXI. La investigación profundiza en torno a los debates políticos e ideológicos sobre la emigración italiana en la Argentina y las diferentes posiciones enfrentadas que conforman el núcleo de esta investigación.

\footnotetext{
- Magister en Literatura Argentina Contemporánea (FFyL, UNCuyo); profesora y licenciada en Letras con orientación en Literatura Clásica (FFyL, UNCuyo) y profesora de Italiano. Doctoranda en Letras, orientación Literatura Italiana del siglo XX (FFyLetras, UNCuyo). Es profesora adjunta de Literatura Italiana (FFyL, UNCuyo) y se desempeña en el Profesorado de Italiano de la misma facultad. Ha trabajado en instituciones de nivel medio y superior en enseñanza de la lengua italiana. En 1991 fue becaria del gobierno italiano en la Università per Stranieri di Perugia.
} 
Algunas de las cuestiones claves abordadas por la investigadora son la construcción de la identidad y la alteridad, el constructo de nación o patria, la estructuración vivencial e imaginaria de los espacios, las causas y las consecuencias de la emigración, el contexto sociocultural y político-económico de Italia y de la Argentina.

El corpus abordado incluye textos literarios canónicos y otros considerados marginales, narraciones autobiográficas, cartas, canciones populares, escritos y discursos rescatados del olvido por su alto valor documental y fundamentales para la comprensión y el estudio de la historia de la emigración italiana hacia la Argentina.

El interés principal del libro es indagar ciertas claves que involucran al fenómeno migratorio desde las perspectivas ideológicas que lo determinan: «alteridad, identidad, nación y patria» y en particular, la construcción de imaginarios sobre el inmigrante, visibles en modalidades discursivas que lo reflejan, al tiempo que se indaga en las inscripciones sociales que modelizan a este tipo de sujeto cultural en un contexto particular, el de su radicación.

La extensa bibliografía consultada abarca desde el siglo XIX al XXI. Bravo Herrera enriquece su búsqueda y perspectiva teórica con canciones y películas que reviven imágenes conmovedoras e impactan al lector o espectador (el caso de las imágenes) haciéndolo pensar en la aventura de tantos inmigrantes de distintas edades y regiones de Italia, lanzados al desafío de llegar al nuevo mundo.

Para completar la documentación, la investigadora se reunió con autores y especialistas en cuestiones migratorias. El libro también cuenta con algunas ilustraciones que el artista ferrarés Arnaldo Ferraguti realizó para la edición de la obra Sull'Oceano de Edmondo De Amicis (Milán, Fratelli Treves, 1890).

Dividido en siete capítulos, el volumen trata, desde ópticas distintas y por cierto muy enriquecedoras, el tema migratorio, por lo que cada uno de ellos tiene títulos que los identifican:

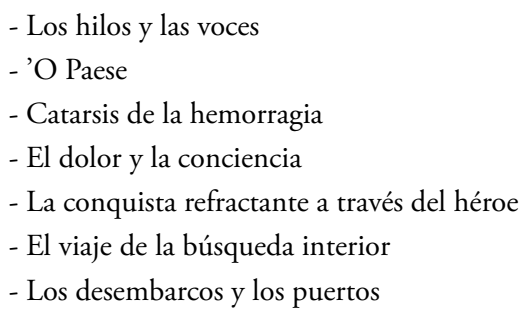

A modo de introducción, cada capítulo va acompañado de fragmentos de cuentos, novelas, poemas, discursos sociales de hondo contenido vivencial.

Una serie de abordajes teóricos confluyen y se complementan en la realización del estudio: la propuesta bajtiniana, que considera la sociabilidad de la cultura y considera al texto literario construido con el rumor social en voces plurales (perspectiva sociocrítica), la Teoría de la Cultura, la Semiótica y la Lecturología de Umberto Eco. A estas perspectivas se añaden aportes del New criticism, estudios filosófico-antropológicos y estudios de crítica literaria que indagan representaciones, imaginarios sobre una parte o porción de la emigración italiana que ha quedado marginada por otros críticos literarios.

Bravo Herrera se propone reconocer en distintos tipos de textos, tanto del ámbito privado como público (sean relatos, obras de teatro, cartas, canciones, proverbios, oraciones religiosas, rezos, pinturas, fotografías, discursos), marcas o huellas que 
permitan distinguir características predominantemente sociales, culturales y vivenciales respecto del origen de los distintos inmigrantes, así como su posicionamiento o establecimiento en la tierra nueva que lo recibe, entendiendo ese recibimiento en todas sus reales variantes: como rechazo, estigmatización, abuso, explotación, inserción conveniente, forzosa, adaptación problemática o feliz y considerando los contextos particulares, espacio-culturales en que se dieron. Estos diferentes modos de arraigo se acompañaron de discursos que posteriormente hallaron su plasmación en textos diversos.

El fenómeno emi-inmigratorio italiano, tomado y estudiado en su carácter bifronte, dialoga a su vez con el ámbito literario argentino, que narra la inmigración italiana a través del discurso de la memoria, entendiendo de esta manera la cuestión como un todo tensionado o en tensión constante y reuniendo el concepto de «migración» con sus complementarios inevitables: emigración/inmigración, desde/hacia.

El foco no es solo la partida dolorosa sino también la llegada de los inmigrantes pero atendiendo además al trayecto marino que el viaje supone. A esto se agrega la consideración de las definiciones que estos viajeros inmigrantes poseían del concepto, idea o vivencia de "patria», «nación», que a veces aparece muy desdibujado, deformado o no existía, ya que tantos italianos conocían solo su región, aldea, pueblo (paese) y por tanto la concepción de un concepto mayor, abarcador, integral de identidad ciudadana nacional no se registraba en el sujeto (piamontés, ligur, siciliano, napolitano, toscano). Estos imaginarios eran acotados, se reconstruían progresivamente, se conformaban a través de la suma de experiencias de vida: tanto allá como aquí.

Además, la investigación incluye precisamente la cuestión «del yo y el otro» o «mismidad y alteridad», quién y cómo soy yo en cuanto al otro y viceversa, en cuanto sujeto conocido, semi-desconocido, absolutamente desconocido, amable, hostil, receptivo, en un juego mutuo de interacciones personales/relaciones interpersonales.

¿A qué mundo se pertenece? ¿Al abandonado o al elegido? ¿Qué se cuenta en torno a ellos? ¿Realidades objetivas o vivencias de esas experiencias que pasan inevitablemente por el filtro emocional? Por lo tanto, las perspectivas de pertenencia, las que haya, parciales o totales, son múltiples, relativas, complementarias, inclusive opuestas.

Sea como protagonistas u observadores, el espacio interrelacional que tanto el inmigrante como el nativo ocupan es fecundo porque dice, expresa y trasunta mucha y valiosa información.

El acierto de la investigación radica además en poner de manifiesto una trayectoria tanto exterior como interior, con sus variaciones, modulaciones, movimientos pendulares y resultados (logrados parcial o totalmente, escasamente logrados) y, en perfilar un recorrido de carácter heroico de los protagonistas. De estigmatizaciones o marginaciones padecidas a la generación de conductas de autoconfianza/autoestima necesarias con el fin de reformular roles tendientes al respeto, a la inserción y al progreso beneficioso para sí y para la comunidad receptora en la que la acción del emigrado extranjero halla eco y ejemplaridad: voluntad de transformación basada en la recuperación de un «ser» que puede saber y llegar a ser referente de poder en su acepción más positiva y edificante. 